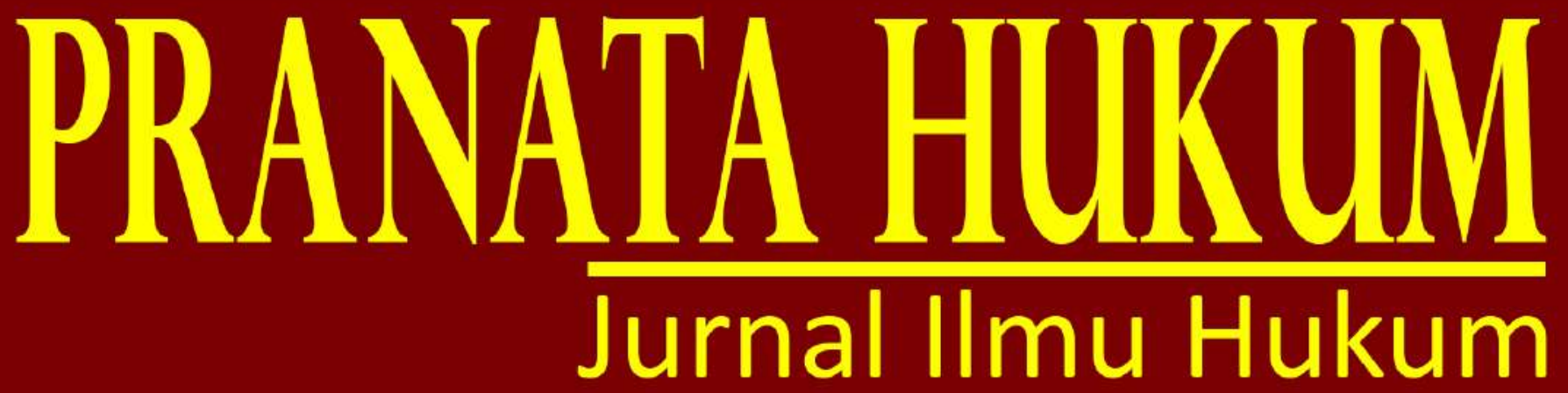

e-ISSN 2685-3213 | p-ISSN 1907-560X

SINERGITAS PEMERINTAHAN DESA DALAM PEMBENTUKAN PERATURAN DESA Anggalana

PENYELESAIAN SENGKETA PERBANKAN BERKAITAN DENGAN PERLINDUNGAN KONSUMEN Dian Herlambang, Muhammad Ridho Wijaya

ANALISIS KOMPARASI ANTARA PERLINDUNGAN PATEN BIASA DENGAN PATEN SEDERHANA BERDASARKAN UNDANG-UNDANG PATEN

Erlina, Melisa Safitri

KONSEPSI NEGARA HUKUM PANCASILA DAN IMPLEMENTASINYA DI INDONESIA Tubagus Muhammad Nasarudin

ANALISIS KEBIJAKAN PEMUNGUTAN RETRIBUSI PELAYANAN PERSAMPAHAN KEBERSIHAN DALAM RANGKA PENINGKATAN PENDAPATAN ASLI DAERAH DI KOTA BANDAR LAMPUNG Pertiwi Agustina RA, Lintje Anna Marpaung, Herlina Ratna Sumbawa Ningrum

ANALISIS KEDUDUKAN PERATURAN DESA PASCA PENGESAHAN UNDANG-UNDANG NOMOR 6 TAHUN 2014 TENTANG DESA DI DESA BADRAN SARI DAN NAMBAH REJO KABUPATEN LAMPUNG TENGAH

Baharudin, Indah Satria, Ramanda Ansori

FANATISME DAN EKSISTENSI NILAI-NILAI DEMOKRASI KADER NAHDLATUL ULAMA KOTA METRO PADA PILPRES 2019

Hendra Irawan, Ika Selviana

PERLINDUNGAN HUKUM TERHADAP PEMENANG LELANG BARANG RAMPASAN NEGARA BERUPA KENDARAAN RODA DUA YANG DIEKSEKUSI DENGAN CARA LELANG OLEH KEJAKSAAN

Okta Vianus Puspa Negara, Zainab Ompu Jainah, S. Tri Herlianto

ANALISIS PERTANGGUNGJAWABAN PELAKU TINDAK PIDANA MENGGANDAKAN SURAT PALSU UNTUK BEKERJA DI PT. GREAT GIANT PINEAPPLE HUMAS JAYA

Helmi Rangkuti, Ketut Seregig, Tami Rusli

MAGISTER HUKUM

UNIVERSITAS BANDAR LAMPUNG

\begin{tabular}{c|c|c|c|l}
$\begin{array}{c}\text { PRANATA } \\
\text { HUKUM }\end{array}$ & $\begin{array}{c}\text { Volume } \\
15\end{array}$ & $\begin{array}{c}\text { Nomor } \\
1\end{array}$ & $\begin{array}{c}\text { Halaman } \\
1-119\end{array}$ & $\begin{array}{l}\text { Bandar } \\
\text { Lampung } \\
\text { Januari } 2020\end{array}$ \\
\hline
\end{tabular}




\section{PRANATA HUKUM}

Jurnal Ilmu Hukum

Magister Hukum

Universitas Bandar Lampung

Terbit Pertama Kali, Juli 2006

Terbit Dua Kali Setahun, Setiap Januari dan Juli

EDITOR IN-CHIEF

Prof. Dr. Lintje Anna Marpaung, S.H., M.H

EDITORIAL BOARDS MEMBERS

Dr. Bambang Hartono, S.H., M.Hum

Dr. Tami Rusli, S.H., M.Hum

Dr. Erlina B, S.H., M.H

Dr. Zainab Ompu Jainah, S.H., M.H

Dr. Zulfi Diane Zaini, S.H., M.H

MANAGING EDITOR

Indah Satria, S.H., M.H

ASSISTANT EDITORS

Yulia Hesti, S.H., MH

Shany Carolina Mawuntu

\section{PENYUNTING AHLI (MITRA BESTARI)}

Prof. Dr. I Gusti Ayu Ketut Rachmi Handayani, S.H., M.M (Universitas Sebelas Maret)

Prof. Dr. I Gede A.B Wiranata, S.H., M.H (Universitas Lampung)

Dr. Nurhadiantomo, S.H., M.Hum (Universitas Muhammdiyah Surakarta)

Dr. Erina Pane, S.H., M.H (UIN Lampung)

\section{Alamat: \\ Kampus B Universitas Bandar Lampung}

Jl. Z.A Pagar Alam No.89 Labuhan Ratu, Bandar Lampung 35142

Telp: 0721-789825 Fax: 0721-770261

Email: jurnal.mh@ubl.ac.id

Jurnal PRANATA HUKUM dimaksudkan sebagai media komunikasi ,edukasi dan informasi ilmiah bidang ilmu hukum. Sajian dan kemasan diupayakan komunikatif melalui bahasa ilmiah.

Redaksi mengundang semua elemen masyarakat ,baik civitas akademika, praktisi , lembaga masyarakat, maupun perorangan yang berminat terhadap bidang hukum untuk berpartisipasi mengembangkan gagasan, wawasan, dan pengetahuan melalui tulisan untuk dimuat dalam jurnal ini. Melalui PRANATA HUKUM diharapkan terjadi proses pengembangan bidang hukum sebagai bagian penting dari rangkaian panjang proses memajukan masyarakat bangsa 


\title{
SINERGITAS PEMERINTAHAN DESA DALAM PEMBENTUKAN PERATURAN DESA
}

\author{
Anggalana ${ }^{1}$
}

\begin{abstract}
The synergy between the Village Head and the Village Consultative Body (BPD) in the Process of Forming Village Regulations, is manifested in the form of partnership, where the position between the Village Consultative Body (BPD) and the Village Government is in line with the authority possessed in different formations, starting from the stages of planning, drafting, discussing, determining and determining enactment and dissemination of Village Regulations. In addition, the Village Consultative Body (BPD) has the authority to also have the oversight function of the implementation of the Village Regulation by the Village Head. Meanwhile, if the Village Regulation cannot be carried out properly and is unable to bring justice to the community, the Village Consultative Body (BPD) has the authority to cancel the Village Regulation that has been jointly determined, with the Village Head or that has been implemented by the Village Head where the Village Consultative Body (BPD) can submit cancellation. The Village Regulation is sent to the District Government through the District Head to conduct an evaluation of the Village Regulation.
\end{abstract}

\section{Keywords: Synergy, Village Government, Village Regulations.}

\section{PENDAHULUAN}

Negara Indonesia adalah negara hukum, yang melandaskan segala bentuk penyelenggaraan negaranya berdasarkan aturan-aturan hukum yang mengacu kepada konstitusi, dalam rangka mewujudkan pemerintahan yang baik (Good Governance). Tata Pemerintahan yang baik adalah sebuah tata Pemerintahan yang dikembangkan atas dasar prinsip efisiensi dan efektifitas, partisipasi, responsifitas, kesamaan di muka hukum keadilan dan orientasi pada konsensus. Sebaliknya tata Pemerintahan yang buruk adalah tata Pemerintahan yang diselenggarakan dengan mengabaikan nilai-nilai di atas. ${ }^{2}$ Secara teoritis, jika mengacu pada konsep Trias Politika (terlepas dari kekuasaan yudikatif) negara berdasarkan konstitusi harus bersandarkan pada kekuatan legislatif. Di samping itu, ada kekuasaan eksekutif yang berfungsi melaksanakan undang-undang. Badan legislatif dan eksekutif

1 Dosen Fakultas Hukum Universitas Bandar Lampung, anggalana@ubl.ac.id

${ }^{2}$ Agus Dwiyanto, dkk. 2003. Reformasi Tata Pemerintahan dan Otoromi Daerah. Pusat Studi Kependudukan dan Kebijakan Universitas Gadjah Mada, Yogyakarta, hlm. 6. 
mengurusi warga negara dan menjamin hak warganya agar merasa aman. ${ }^{3}$ Kekuatan legislatif ada batasnya dan didasarkan konstitusi. Pertama, kekuasaan legislatif dalam menjalankan wewenangnya harus berdasarkan undang-undang yang pasti dan diumumkan kepada rakyat untuk dimengerti (promulgated established laws). Kedua, pengambilan hak rakyat oleh kekuasaan legislatif harus terjadi dengan persetujuan rakyat. Ketiga, kekuasan legislatif tidak boleh melemparkan tugas atas tanggung jawabnya kepada kekuasaan lain. Kekuasaan eksekutif merupakan kekuasaan tertinggi dalam pelaksanaan undang-undang berdasarkan kuasa atau mandat dari kuasa legislatif. Kekuasaan eksekutif meskipun terpisah dari kekuasaan legislatif, namun keduanya masih mempunyai hubungan erat. Pemisahan kekuasan ini hanya mengandung makna dalam rangka mengadakan kontrol terhadap pelaksanaan kekuasaan atau mandat dari kekuasaan legislatif kepada eksekutif.

Sejalan dengan prinsip tersebut, dalam lingkup yang lebih sempit (Pemerintahan Desa), maka akan terlihat yaitu dengan adanya Badan Permusyawatan Desa (BPD) sebagai lembaga legislatif dan Kepala Desa sebagai kepala eksekutif yang dalam penyelenggaraan Pemerintahan Desa akan saling berhubungan dan saling membutuhkan antara satu dengan lainya. Apabila hubungan tersebut berjalan dengan baik akan bermuara kepada good governance. Indikator adanya hubungan antara Kepala Desa dengan Badan Permusyawatan Desa (BPD) antara lain ada dalam hal penyelenggaraan Pemerintahan Desa dan dalam hal penyusunan, pembahasan, serta penetapan Peraturan Desa. Dimasukkannya Pemerintahan Desa sebagai satu kesatuan dalam Undang-Undang Pemerintahan Daerah, apabila ditinjau dari politik Pemerintahan, mempunyai makna penting. Sebagai salah satu bagian Pemerintahan Daerah, desa sudah semestinya mendapatkan segala status dan kedudukan, beserta berbagai unsur Pemerintah Daerah seperti provinsi, kabupaten, atau kota. ${ }^{4}$

Sebagai Pemerintahan Daerah, desa memiliki seluruh tatanan Pemerintahan otonom yang mandiri dalam menjalankan segala urusan rumah tangganya. Susunan organisasi dan Pemerintahan Desa tidak lagi sekedar cermin sejarah Pemerintahan masa lalu dengan segala keaslian tradisional. Pemerintahan Desa harus menjadi bagian integral dari Pemerintah Negara Republik Indonesia yang menjalankan fungsi-fungsi Pemerintahan baru. Salah satu unsur paling penting adalah pembaharuan Pemerintahan tradisional desa agar dapat menjalankan fungsi Pemerintahan dan pelayanan seirama dengan perkembangan masyarakat sekelilingnya. Pembaharuan yang dimaksud adalah pada segi-segi pengelolaan, pengembangan sumber daya yang ada, orientasi Pemerintahan dan lain-lain. ${ }^{5}$ hlm. 25.

${ }^{3}$ Siswanto Sunarno. 2006. Hukum Pemerintahan Daerah di Indonesia. Sinar Grafika, Jakarta,

${ }^{4}$ Bagir Manan. 2005. Menyongsong Fajar Otonomi Daerah. Pusat Studi Hukum Fakultas Hukum Universitas Islam Indonesia, Yogyakarta, hlm. 159.

${ }^{5}$ Ibid, hlm. 159-160. 
Penyelenggaraan Pemerintahan Desa merupakan subsistem penyelenggaraan Pemerintahan, sehingga desa memiliki kewenangan untuk mengatur dan mengurus kepentingan masyarakatnya. Agar Pemerintahan Desa dapat berjalan dengan baik maka hal pokok yang harus diperhatikan adalah dengan melihat hubungan serta kinerja Kepala Desa selaku Kepala Pemerintah Desa dengan Badan Permusyawaratan Desa sebagai representasi dari warga desa. Melihat keberadaan Badan Permusyawatan Desa (BPD) sebagai mitra kerja dari Kepala Desa, maka tidak dapat disangsikan lagi bahwa di antara kedua lembaga kekuasaan tersebut terdapat hubungan yang tidak terpisahkan. Salah satu tindak lanjut atas Undang-Undang Nomor 9 Tahun 2015 tentang Perubahan Kedua Atas Undang-Undang Nomor 23 Tahun 2014 tentang Pemerintahan Daerah, maka Pemerintah menerbitkan Peraturan Pemerintah Nomor 47 Tahun 2015 tentang Perubahan Atas Peraturan Pemerintah Nomor 43 Tahun 2014 tentang Peraturan Pelaksanaan Undang-Undang Nomor 6 Tahun 2014 tentang Desa. Isi dari peraturan Pemerintah tersebut antara lain mengatur tentang penyelenggaraan Pemerintahan Desa. Dalam Pasal 11 disebutkan bahwa Pemerintahan Desa terdiri dari Pemerintah Desa dan Badan Permusyawatan Desa (BPD). ${ }^{6}$

Keberadaan Badan Permusyawaratan Desa dalam Peraturan Pemerintah tersebut diatur dalam Pasal 29 yang menyebutkan "Badan Permusyawatan Desa (BPD) berkedudukan sebagai unsur penyelenggara Pemerintahan Desa"7, selanjutnya dalam Pasal 30 ayat (1) disebutkan "anggota BPD adalah wakil dari penduduk desa bersangkutan berdasarkan keterwakilan wilayah yang ditetapkan dengan cara musyawarah dan mufakat"8, sedangkan tugas Kepala Desa diatur dalam Pasal 14 ayat (2) yang menyebutkan "Kepala Desa mempunyai tugas menyelenggarakan urusan Pemerintahan, pembangunan, dan kemasyarakatan", sedangkan wewenang Kepala Desa diatur dalam ayat (2) Peraturan Pemerintah Nomor 47 Tahun 2015 tentang Perubahan Atas Peraturan Pemerintah Nomor 43 Tahun 2014 tentang Peraturan Pelaksanaan Undang-Undang Nomor 6 Tahun 2014 tentang Desa9.

Berkaitan dengan pembentukan Peraturan Desa, secara umum inisiatif Kepala Desa masih lebih banyak dibandingkan inisiatif Badan Permusyawatan Desa (BPD). Namun demikian Kepala Desa tidak kemudian meninggalkan Badan

${ }^{6}$ Lihat Pasal 11 Peraturan Pemerintah Nomor 47 Tahun 2015 tentang Perubahan Atas Peraturan Pemerintah Nomor 43 Tahun 2014 tentang Peraturan Pelaksanaan Undang-Undang Nomor 6 Tahun 2014 tentang Desa.

${ }^{7}$ Lihat Pasal 29 Peraturan Pemerintah Nomor 47 Tahun 2015 tentang Perubahan Atas Peraturan Pemerintah Nomor 43 Tahun 2014 tentang Peraturan Pelaksanaan Undang-Undang Nomor 6 Tahun 2014 tentang Desa.

${ }^{8}$ Lihat Pasal 30 ayat (1) Peraturan Pemerintah Nomor 47 Tahun 2015 tentang Perubahan Atas Peraturan Pemerintah Nomor 43 Tahun 2014 tentang Peraturan Pelaksanaan Undang-Undang Nomor 6 Tahun 2014 tentang Desa.

${ }^{9}$ Lihat Pasal 14 ayat (2) Peraturan Pemerintah Nomor 47 Tahun 2015 tentang Perubahan Atas Peraturan Pemerintah Nomor 43 Tahun 2014 tentang Peraturan Pelaksanaan Undang-Undang Nomor 6 Tahun 2014 tentang Desa. 
Permusyawatan Desa (BPD), karena setiap rancangan Peraturan Desa selalu dikomunikasikan, dibahas, dimusyawarahkan, dan atas persetujuan bersama dengan Badan Permusyawatan Desa (BPD) sebelum rancangan Peraturan Desa disahkan sebagai Peraturan Desa.

Meskipun dimungkinkan pembentukan rancangan Peraturan Desa atas inisiatif BPD, namun inisiatif lebih banyak dari Kepala Desa karena Badan Permusyawatan Desa (BPD) hanya berperan membahas dan menyetujuinya. Disamping itu Badan Permusyawatan Desa (BPD) tidak bisa melakukan kontrol atau kritik secara langsung terhadap pelaksanaan Peraturan Desa atau kinerja dari Kepala Desa, sehingga ada beberapa dari Peraturan Desa yang tidak ditaati. Padahal dengan keberadaan Badan Permusyawatan Desa (BPD) diharapkan aspirasi masyarakat secara langsung lebih dapat terakomodasi, baik dalam proses perencanaan Peraturan Desa sampai dengan penetapan Peraturan Desa. Namun keterlibatan masyarakat dalam perencanaan Peraturan Desa dan penetapan Peraturan Desa belum optimal, karena belum semua warga masyarakat mampu menyuarakan aspirasinya sehingga berdampak pula tidak terwujudnya kerjasama antara aparatur desa dengan masyarakat seperti pihak pamong desa (dalam hal ini Kepala Desa) yang tidak melaksanakan mekanisme musyawarah dengan Badan Permusyawatan Desa (BPD) untuk membahas kebijakan atau permasalahan yang ada di desa, sedangkan tugas pokok dan kewenangan Badan Permusyawatan Desa (BPD) antara lain mengawasi dan ikut serta dalam pembuatan Peraturan Desa serta Rancangan Anggaran Pendapatan dan Belanja Desa (RAPBDes). Dengan demikian prinsip check and balances antara pihak legislative (BPD) dengan pihak eksekutif (Kepala Desa) belum terwujud sehingga berdampak pula terhadap tidak terwujudnya pemerintahan di desa yang baik (good governance)

\section{PEMBAHASAN}

\section{A. Negara Hukum}

Pasal 1 ayat (3) Undang-Undang Dasar Negara Republik Indonesia Tahun 1945 menetapkan "Indonesia adalah negara hukum"10. Mengenai landasan filosofis dari Negara Hukum Indonesia adalah Pancasila. Penegasan ini menunjukkan komitmen lebih tegas dari bangsa dan Negara Indonesia yang berdasarkan Pancasila untuk memberikan kedaulatan hukum dalam penyelenggaraan kehidupan bernegara, berbangsa dan bermasyarakat di wilayah Negara Indonesia. Lawrence M. Friedman mengemukakan bahwa efektif dan berhasil tidaknya penegakan hukum tergantung tiga unsur sistem hukum, yakni struktur hukum (struktur of law), substansi hukum (substance of the law) dan budaya hukum (legal culture). Struktur hukum menyangkut aparat penegak hukum, substansi hukum meliputi perangkat perundang-undangan dan budaya hukum merupakan hukum

\footnotetext{
${ }^{10}$ Pasal 1 ayat (3) Undang-Undang Dasar Negara Republik Indonesia Tahun 1945.
} 
yang hidup (living law) yang dianut dalam suatu masyarakat. Tentang struktur hukum Friedman menjelaskan: Struktur dari sistem hukum terdiri atas unsur berikut ini, jumlah dan ukuran pengadilan, yurisdiksinnya (termasuk jenis kasus yang berwenang mereka periksa), dan tata cara naik banding dari pengadilan ke pengadilan lainnya. ${ }^{11}$

Struktur juga berarti bagaimana badan legislatif ditata, apa yang boleh dan tidak boleh dilakukan oleh badan eksekutif. Jadi struktur (legal struktur) terdiri dari lembaga hukum yang ada dimaksudkan untuk menjalankan perangkat hukum yang ada. Struktur adalah pola yang menunjukkan tentang bagaimana hukum dijalankan menurut ketentuan-ketentuan formalnya. Struktur ini menunjukkan bagaimana pengadilan, pembuat hukum dan badan serta proses hukum itu berjalan dan dijalankan. Substansi hukum menurut Friedman adalah aspek lain dari sistem hukum adalah substansinya. Yang dimaksud dengan substansinya adalah aturan, norma, dan pola perilaku nyata manusia yang berada dalam system itu. Jadi substansi hukum menyangkut peraturan perundang-undangan yang berlaku yang memiliki kekuatan yang mengikat dan menjadi pedoman bagi aparat penegak hukum. ${ }^{12}$ Sedangkan mengenai budaya hukum adalah Kultur hukum menyangkut budaya hukum yang merupakan sikap manusia (termasuk budaya hukum aparat penegak hukumnya) terhadap hukum dan sistem hukum. Sebaik apapun penataan struktur hukum untuk menjalankan aturan hukum yang ditetapkan dan sebaik apapun kualitas substansi hukum yang dibuat tanpa didukung budaya hukum oleh orang-orang yang terlibat dalam sistem dan masyarakat maka penegakan hukum tidak akan berjalan secara efektif. ${ }^{13}$

Hukum sebagai alat untuk mengubah masyarakat atau rekayasa sosial yang tidak lain hanya merupakan ide-ide yang ingin diwujudkan oleh hukum itu. Untuk menjamin tercapainya fungsi hukum sebagai rekayasa masyarakat kearah yang lebih baik, maka bukan hanya dibutuhkan ketersediaan hukum dalam arti kaidah atau peraturan, melainkan juga adanya jaminan atas perwujudan kaidah hukum tersebut ke dalam praktek hukum, atau dengan kata lain, jaminan akan adanya penegakan hukum (law enforcement) yang baik. Jadi bekerjanya hukum bukan hanya merupakan fungsi perundang-undangannya belaka, malainkan aktifitas birokrasi pelaksananya. ${ }^{14}$

Suatu Negara dikatakan sebagai Negara Hukum dapat dilihat dari konstitusi Negara yang bersangkutan. K.C. Wheare menyatakan "what should a constitution contains? The very minimum, and minimum to be rules of law "(isi minimum suatu konstitusi adalah tentang Negara Hukum). ${ }^{15}$ Negara dikatakan sebagai Negara hlm.22.

${ }^{11}$ Lawrence M Friedman.2011. Sistem Hukum Perspektif Ilmu Sosial. Nusa Media Bandung,

12 Ibid.

13 Ibid.

14 Ibid.

15 K. C. Wheare. 2010. Modern Constitution. Oxford University Press, New York, hlm. 33-34. 
Hukum dapat dilakukan melalui penelusuran pandangan ilmiah para ahli, yang memberikan unsur-unsur atau ciri-ciri suatu Negara Hukum. Friedrich Julius Stahl dalam buku A. Mukthie Fadjar mengemukakan ciri-ciri Negara Hukum yaitu:

a) adanya pengakuan akan hak-hak dasar manusia.

b) adanya pembagian kekuasaan.

c) Pemerintahan berdasarkan Peraturan. dan

d) adanya Peradilan Tata Usaha Negara. ${ }^{16}$

Melengkapi pandangan mengenai ciri-ciri Negara Hukum, Frans Magnis Suseno mengemukakan ciri-ciri Negara Hukum sebagai berikut:

a) Asas Legalitas.

b) Kebebasan / kemandirian kekuasaan kehakiman.

c) Perlindungan Hak asasi manusia. dan

d) Sistem Konstitusi / hukum dasar. ${ }^{17}$

Sedangkan negara hukum menurut Joeniarto adalah kekuasaan negara dibatasi oleh hukum (rechtsstaat), bukan didasarkan atas kekuasaan (machtsstaat). Lebih lanjut ditambahkan bahwa tujuan dari Negara Hukum adalah adanya pembatasan kekuasaan negara oleh hukum. Disamping itu suatu negara dapat dikatakan sebagai negara hukum perlu diketahui elemen-elemen atau unsurunsurnya yang tertuang di dalam Undang-Undang Dasar beserta peraturan pelaksanaannya, dan yang terpenting dalam praktek sudah dilaksanakan atau belum. ${ }^{18}$

A. Hamid S. Attamimi yang mengutip pendapat Van Wijk dan Konijnenbelt, di dalam suatu Negara Hukum dapat diketemukan adanya wawasan-wawasan sebagai berikut:

(a) Pemerintahan menurut hukum (wetmatigheid van bestuur), dengan bagianbagiannya tentang kewenangan yang dinyatakan dengan tegas tentang perlakuan yang sama dan tentang kepastian hukum .

(b) perlindungan hak-hak asasi.

(c) Pembagian kekuasaan dengan bagian-bagiannya tentang struktur kewenangan atau desentralisasi dan tentang pengawasan serta kontrol.

(d) pengawasan oleh kekuasaan peradilan. ${ }^{19}$ hlm. 42.

${ }^{16}$ Fadjar, A. Mukthie. 2005. Tipe Negara Hukum. Cet. Kedua. Bayumedia Publishing, Malang,

17 F. Magnis Suseno. 2006. Etika Politik, Prinsip - Prinsip Moral Dasar Kenegaraan Modern. Gramedia, Jakarta, hlm. 298-301.

${ }^{18}$ Joeniarto. 2006. Negara Hukum. Yayasan Badan Penerbit Gadjah Mada, Yogyakarta, hlm. 8.

19 Attamimi, A. Hamid S. 2010. Peranan Keputusan Presiden Republik Indonesia Dalam Penyelenggaraan Pemerintahan Negara, Suatu Studi Analisa Mengenai Keputusan Presiden Yang Berfungsi Pengaturan Dalam Kurun Waktu Pelita I-Pelita IV, Disertasi Universitas Indonesia, Jakarta, hlm. 311. 
Di dalam perkembangan pemikiran filsafat hukum dan teori hukum, menurut Muchsan tentu tidak lepas dari konsep keadilan. Konsep keadilan tindak menjadi monopoli pemikiran satu orang ahli saja. Banyak para pakar dari berbagai didiplin ilmu memberikan jawaban apa itu keadilan. Negara Hukum yang dianut Negara Indonesia tidaklah dalam artian formal, melainkan dalam artian material yang juga diistilahkan dengan Negara Kesejahteraan (Welfare State). ${ }^{20}$

Muchsan dalam kaitan ini menunjukkan bukti-bukti Negara Indonesia sebagai Negara hukum dengan mengacu pada 2 (dua) hal yakni:

(1) Salah satu sila dari Pancasila sebagai dasar falsafah Negara (sila kelima) adalah keadilan sosial. Ini berarti tujuan negara adalah menuju kepada kesejahteraan dari pada warganya;

(2) Dalam Alenia Keempat Pembukaan Undang-Undang Dasar 1945 dikatakan bahwa tujuan pembentukan negara Indonesia, salah satunya adalah memajukan kesejahteraan umum. ${ }^{21}$

Untuk mewujudkan adanya kesejahteraan rakyat, menurut H.Mc.Coubrey and N.D.White negara dan Pemerintah Indonesia tidak hanya bertugas memelihara ketertiban masyarakat, akan tetapi dituntut untuk turut serta secara aktif (proaktif) dalam semua aspek kehidupan dan penghidupan rakyat. Konsekuensinya, lapangan Pemerintahan yang diemban Pemerintah menjadi sangat luas. Lemaire mengemukakan Pemerintah mengemban tugas "Bestuurszorg" yaitu tugas dan fungsi menyelenggarakan kesejahteraan umum. Dengan semakin banyaknya campur tangan Pemerintah/negara dalam berbagai kehidupan masyarakat, bagi Negara Hukum Modern seperti Indonesia, tindakan Pemerintah tersebut jelas harus dilandasi aspek-aspek hukum agar tindakan atau perbuatan Pemerintah/Negara tersebut tidak menimbulkan konflik di kemudian hari. ${ }^{22}$

Sebagaimana disebutkan oleh Norbert Wiener dalam H.Mc.Coubrey and N.D.White bahwa " Law may be defined as the ethical control applied to communication, and to language as a form of communication, especially when this normative aspect is under the control of some authority sufficiently strong to give its decisions an effective social sanction". Pada pihak lain, John Austin menyatakan bahwa: "The most essential characteristic of positive law, consistsin it's imperative character. Law is conseived as a command of the sovereign. Bahwa hukum adalah perintah dari penguasa negara dimana hakikat dari hukum itu sendiri terletak pada unsur perintah. Dari konsep tersebut di atas dipandang perlu adanya suatu perlindungan oleh Pemerintah terhadap masyarakat melalui peraturan berupa hukum positif yang bersifat memaksa. ${ }^{23}$

${ }^{20}$ Muchsan. 2012. Pengantar Hukum Administrasi Negara. Liberty, Yogyakarta, hlm. 70.

$21 \mathrm{Ibid}, \mathrm{hlm} .72$.

${ }^{22}$ H.Mc.Coubrey and N.D.White. 2003. Text Book On Jurisprudensi. Blakstone Press Limited, London, Page.14.

${ }^{23}$ Ibid. 


\section{B. Otonomi Daerah}

Istilah Otonomi Daerah menurut Purwadarminta dalam Kamus Besar Bahasa Indonesia berasal dari Bahasa Yunani outonomos autonomia yang berarti "keputusan sendiri". ${ }^{24}$ Menurut Ismulyadi, otonomi dapat mengandung beberapa pengertian, Otonomi Daerah:

1. Suatu kondisi atau ciri untuk tidak dikontrol oleh pihak lain ataupun kekuatan luar.

2. Bentuk Pemerintahan sendiri (Self-Government), yaitu hak untuk memerintah atau menentukan nasib sendiri (The right of sells government: self-determination).

3. Pemerintahan otonomi memiliki pendapatan yang cukup untuk menentukan nasib sendiri, memenuhi kesejahteraan hidup maupun dalam mencapai tujuan hidup secara adil (self-determination, self-sufficiency, selfreliance).

4. Pemerintah otonomi memiliki supremasi/dominasi kekuasaan (Supremacy of authority) atau hukum yang dilaksanakan sepenuhnya oleh pemegang kekuasaan di daerah. ${ }^{25}$

Menurut Indra Ismawan otonomi yang luas, nyata dan bertanggung jawab itu adalah:

a. Kewenangan otonomi yang luas adalah keleluasaan daerah untuk menyelenggarakan Pemerintahan yang mencakup kewenangan semua bidang Pemerintahan, kecuali kewenangan di bidang politik luar negeri, pertahanan keamanan, peradilan, moneter dan fiskal, agama, serta kewenangan bidang lainnva (yang ditetapkan dengan Peraturan Pemerintah Nomor 25 Tahun 2000). Di samping itu keleluasaan otonomi mencakup pula kewenangan yang utuh dan bulat dalam penyelenggaraan mulai dari perencanaan, pelaksanaan, pengawasan, pengendalian dan evaluasi.

b. Otonomi nyata adalah keleluasaan daerah untuk menyelenggarakan kewenangan Pemerintahan di bidang tertentu yang secara nyata ada dan diperlukan serta tumbuh, hidup dan berkembang di daerah.

c. Otonomi yang bertanggung jawab ada berupa perwujudan pertanggungjawaban sebagai konsekuensi pemberian hak dan kewenangan kepada daerah dalam wujud tugas dan kewajiban yang harus dipikul oleh daerah dalam mencapai tujuan pemberian otonomi, berupa peningkatan pelayanan dan kesejahteraan masyarakat yang semakin baik, pengembangan kehidupan demokrasi, keadillan dan pemerataan serta pemelihara

${ }^{24}$ Purwadarminta. 2008. Kamus Besar Bahasa Indonesia. Balai Pustaka, Jakarta, hlm. 152.

${ }^{25}$ Ismulyadi dkk. 2000. Otonomi Daerah, Demokrasi dan Cipil Society. Media Grafika Cetakan 1, Jakarta, hlm 13. 
hubungan yang serasi antara Pusat dan Daerah serta antar Daerah dalam rangka menjaga keutuhan Negara Kesatuan Republik Indonesia. ${ }^{26}$

Otonomi Daerah merupakan perwujudan pelaksanaan asas desentralisasi dalam penyelenggaraan Pemerintahan suatu negara. Berdasarkan asas tersebut kekuasaan negara akan terbagi antara Pemerintah Pusat disatu pihak dan Pemerintah Daerah di lain pihak. Adanya pembagian kekuasaan dalam rangka Otonomi Daerah pada masing-masing negara tidak sama, tergantung kepada sistem dan kehendak politik Pemerintah dalam memberikan kekuasaan tersebut. Dalam tatanan negara kesatuan, maka akan terjadi dominasi atas daerah atau dominasi Pemerintah atas masyarakat. Dengan bertambahnya kepentingan yang harus diselenggarakan oleh Pemerintah Pusat.

Menurut Amrah Muslimin, Pemerintah tidak dapat mengurus semua kepentingan-kepentingan itu dengan baik tanpa berpegang pada asas-asas kedaerahan dalam melakukan pemerintahan. ${ }^{27}$ Amrah Muslimin mengemukakan bahwa asas kedaerahan mengandung dua macam prinsip yaitu:

1) Dekonsentrasi, yaitu pelimpahan sebagian dari kewenangan Pemerintah Pusat pada alat-alat Pemerintah Pusat yang ada di daerah.

2) Desentralisasi, yaitu pelimpahan wewenang dari Pemerintah Pusat yang menimbulkan hak mengurus kepentingan rumah tangga sendiri bagi badanbadan politik di daerah. ${ }^{28}$

Dapat dikatakan bahwa asas dekonsentrasi merupakan perpanjangan tangan dari Pemerintah Pusat yang melaksanakan pemerintahan sentral di daerah-daerah. Dengan asas dekonsentrasi Pemerintah Daerah masih tetap terikat oleh instruksi Pemerintah Pusat dan tidak memiliki kebebasan yang cukup luas dalam menyelenggarakan kepentingan masyarakat di daerah. Sedangkan desentralisasi adalah pemberian hak dan wewenang kepada daerah sebagai suatu masyarakat hukum untuk mengatur dan mengurus rumah tangganya sendiri. Ini berarti dengan asas desentralisasi, maka kepada daerah diberikan kebebasan untuk menyelenggarakan kepentingan masyarakat di daerahnya.

Otonomi daerah menurut Moh. Mahfud MD pemberian kebebasan untuk mengurus rumah tangga sendiri, tanpa mengabaikan kedudukan pemerintah daerah sebagai arapat pemerintah pusat untuk menyelenggarakan urusan-urusan yang ditugaskan kepadanya. ${ }^{29}$ Berdasarkan uraian tersebut di atas dapat dipahami bahwa banyak kemandirian suatu Daerah yang menjadi kabupaten baru untuk melaksanakan Otonomi Daerah yang seluas-luas bagi daerah yang mau menjalan Otonomi Daerah adalah hak dan wewenang suatu Daerah mengatur dan mengurus sendiri suatu Daerah Otonomi Daerah baru. Tak dapat dipungkiri, bahwa

26 Indra Ismawan. 2002. Raniau-Ranlau Otonomi Daerah. Pondok Edukasi, Solo, hlm 135.

${ }^{27}$ Amrah Muslimin. 2006. Aspek-aspek Hukum Otonomi Daerah. Alumni, Bandung, hlm 4.

${ }^{28}$ Ibid. hlm 6.

${ }^{29} \mathrm{Ibid}$, hlm. 49. 
perubahan dinamika kewenangan Permerintah Pusat ke daerah menimbulkan konsekuensi.

\section{Pemerintahan Desa}

Dalam perjalanan ketatanegaraan Republik Indonesia, desa telah berkembang dalam berbagai bentuk sehingga perlu dilindungi dan diberdayakan agar menjadi kuat, maju, mandiri dan demokratis sehingga dapat menciptakan landasan yang kuat dalam melaksanakan pemerintahan dan pembangunan menuju masyarakat adil, makmur dan sejahtera. Secara lebih operasional Undang-Undang Otonomi Daerah mengamanatkan bahwa penyelenggaraan pemerintahan diarahkan untuk memberikan kewenangan yang lebih luas kepada Pemerintah Daerah dengan maksud untuk meningkatkan pelayanan dan partisipasi aktif masyarakat terhadap pembangunan di segala bidang. Dalam peraturan tersebut, desa sebagai bagian dari Pemerintahan Daerah Kabupaten yang berhubungan langsung dengan masyarakat, tentunya mempunyai hubungan yang lebih dekat dengan masyarakat ${ }^{30}$. Selain itu, desa memiliki wewenang untuk mengatur dan mengurus kepentingan masyarakat dengan berpedoman pada keanekaragaman, partisipasi otonomi asli, demokrasi dan pemberdayaan masyarakat. Karena itu, Desa diharapkan dapat meningkatkan pelayanan public, dan partisipasi masyarakat dalam proses pelakasanaan pembangunan. ${ }^{31}$

Konsekuensi dari konsep atau gagasan hukum Negara Kesatuan Republik Indonesia (NKRI) bukan saja hanya desentralisasi kewenangan kepada daerah otonom yang melahirkan otonomi daerah, melainkan lebih dari itu yakni pengakuan - ataupun perlindungan terhadap - adanya otonomi desa sebagai otonomi asli bangsa Indonesia sejak sebelum datangnya kolonial Belanda. Pengakuan dimaksud bukan hanya di atas kertas saja seperti kebebasan memberikan nama desa dan sebagainya, tetapi juga harus memberikan implementasi pengakuan terhadap kewenangan desa, terutama kewenangan asli (oroginair) yang telah turun temurun diketahui sebagai kewenagan desa. Dalam hal ini yang harus dijadikan patokan adalah pengakuan atas "keanekaragaman" sebagai dasar pemikiran dalam desain otonomi desa. Perlindungan konstitusi terhadap otonomi desa secara implisit juga diatur dalam Pasal 28I UUD 1945, yang menegaskan bahwa: "identitas budaya dan hak masyarakat tradisional dihormati selaras dengan perkembangan zaman dan peradaban". ${ }^{32}$

30 Sutoro Eko. 2005. Masa Lalu, MasaKini dan Masa Depan Otonomi Desa, dalam Soetandyo Wignosubroto dkk (Tim Penulis). 2005. Pasang surut Otonomi Daerah, Sketsa Perjalanan 100 Tahun. Institute for Local Development dan Yayasan Tifa, Jakarta, hlm 527-529.

31 Ibid.

32 Ateng Syafrudin dan Suprin Na'a. 2010. Republik Desa, Pergulatan Hukum Tradisional dan Hukum Modern dalam Desain Otonomi Desa. Alumni ,Bandung, hlm. 11. 
Menurut Bagir Manan setidaknya dalam pengakuan terhadap keanekaragaman (pluralitas) otonomi desa, harus tampak dalam 2 (dua) hal, yakni: Pertama, pemerintahan desa tidak harus mempergunakan nama desa. Diperbolehkan mempergunakan nama menurut adat istiadat seperti dusun, marga, nagari, meunasah, gampong, negorij dan lain sebagainya. Kedua, pengakuan terhadap otonomi asli desa. ${ }^{33}$ Otonomi desa yang nyata dilihat melalui pelaksanaan asas rekognisi dan subsidiaritas. Asas rekognisi mengisyaratkan adanya pengakuan terhadap kesatuan masyarakat hukum atau kesatuan Masyarakat Hukum Adat yang bekaitan dengan eksistensi desa, hak-hak tradisional dan prakarsa desa sebagai subjek dalam pemerintahan desa.

Begitu pula, dengan asas subsidiaritas yang mengisyaratkan bahwa merupakan organisasi Pemerintahan berbasis masyarakat, Pemerintahan yang menyatu dengan masyarakat atau pemerintahan milik masyarakat atau Pemerintahan paling depan, paling bawah dan paling dekat dengan masyarakat ${ }^{34}$. Kedua asas utama tersebut, memberikan implikasi terhadap pendefenisian dan pemaknaan desa. Terbukti, dalam mendefenisikan desa Pasal 1 ayat (1) UndangUndang Nomor 6 Tahun 2014 Tentang Desa menyebutkan bahwa, "Desa adalah desa dan desa adat atau yang disebut dengan nama lain, selanjutnya disebut desa, adalah kesatuan masyarakat hukum yang memiliki batas wilayah yang berwenang untuk mengatur dan mengurus urusan pemerintahan, kepentingan masyarakat setempat berdasarkan prakarsa masyarakat, hak asal usul, dan/atau hak tradisional yang diakui dan dihormati dalam sistem pemerintahan Negara Kesatuan Republik Indonesia."35

Berdasarkan uraian di atas, maka dapat disimpulkan bahwa pembentukan peraturan perundang-undangan oleh pemerintah pusat, menghasilkan dua modelisasi otonomi desa yaitu otonomi desa asli (bagi desa yang masih menerapkan adat istiadat dalam kehidupan kesatuan masyarakatnya) dan otonomi desa desentralisasi (bagi desa yang masyarakatnya cenderung heterongen akibat perkembangan masyarakat), otonomi ini merupakan pemberian dari pemerintahan yang lebih tinggi dan tidak menggunakan hukum adat dalam penyelenggaraan pemerintahannya, melainkan menggunakan hukum formal.

\section{Peraturan Desa}

Peraturan Desa secara harfiah terdiri dari dua (2) kosakata yakni Peraturan dan Desa. Peraturan menurut Kamus Besar Bahasa Indonesia adalah petunjuk, kaidah, ketentuan yang dibuat untuk mengatur. sedangkan Desa adalah kesatuan wilayah yang dihuni oleh sejumlah keluarga yang mempunyai sistem

\footnotetext{
33 Bagir Manan. Op.Cit. hlm. 161-162.

${ }^{34}$ Ni"matul Huda. 2015. Hukum Pemerintahan Desa. Setara Press, Malang, hlm. ke 8-9.

35 Pasal 1 ayat (1) Undang-Undang Nomor 6 Tahun 2014 Tentang Desa.
} 
pemerintahan sendiri (dikepalai oleh seorang kepala desa). ${ }^{36}$ Berdasarkan ketentuan Pasal 1 ayat (7) Undang-Undang Nomor 6 Tahun 2014 dikatakan bahwa Peraturan Desa adalah peraturan perundangundangan yang ditetapkan oleh Kepala Desa setelah dibahas dan disepakati bersama Badan Permusyawaratan Desa. Berdasarkan ketentuan Undang-Undang Nomor 6 Tahun 2014 Tentang Desa muatan materi yang terkandung dalam Peraturan Desa meliputi:

a) kewenangan berdasarkan hak asal usul;

b) kewenangan lokal berskala Desa;

c) kewenangan yang ditugaskan oleh Pemerintah, Pemerintah Daerah Provinsi, atau Pemerintah Daerah Kabupaten/Kota; dan

d) kewenangan lain yang ditugaskan oleh Pemerintah, Pemerintah Daerah Provinsi atau Pemerintah Daerah Kabupaten/Kota sesuai dengan ketentuan peraturan perundang-undangan. ${ }^{37}$

Pelaksanaan kewenangan berdasarkan hak asal-usul dan kewenangan lokal berskala Desa diatur dan diurus oleh Desa. Pelaksanaan kewenangan yang ditugaskan dan pelaksanaan kewenangan tugas lain dari Pemerintah, Pemerintah Daerah Provinsi, atau Pemerintah Daerah Kabupaten/Kota diurus oleh Desa. Penugasan dari Pemerintah dan/atau Pemerintah Daerah kepada Desa meliputi penyelenggaraan Pemerintahan Desa, pelaksaan Pembangunan Desa, pembinaan kemasyarakat Desa, dan Pemberdayaan masyarakat Desa. Penugasan tersebut disertai biaya.

Penyelenggaraan kewenangan desa berdasarkan hak asal usul dan kewenangan lokal berskala Desa didanai oleh APBDesa. Penyelenggaraan kewenangan lokal berskala Desa selain didanai oleh APBDesa, juga dapat didanai oleh APBN dan APBD. Penyelenggaran kewenangan desa yang ditugaskan oleh Pemerintah didanai APBN yang dialokasikan pada bagiananggaran kementrian/lembaga dan disalurkan melalui satuan kerja perangkat daerah kabupaten/kota. Penyelenggaran kewenangan desa yang ditugaskan oleh Pemerintah Daerah didanai oleh APBD. Pelaksanaan kewenangan berdasarkan hak asal-usul dan kewenangan lokal berskala Desa diatur dan diurus oleh Desa. Pelaksanaan kewenangan yang ditugaskan dan pelaksanaan kewenangan tugas lain dari Pemerintah, Pemerintah Daerah Provinsi, atau Pemerintah Daerah Kabupaten/Kota diurus oleh Desa.

Penugasan dari Pemerintah dan/atau Pemerintah Daerah kepada Desa meliputi penyelenggaraan Pemerintahan Desa, pelaksanaan Pembangunan Desa, pembinaan kemasyarakat Desa, dan Pemberdayaan masyarakat Desa. Penugasan tersebut disertai biaya. Penyelenggaraan kewenangan desa berdasarkan hak asal usul dan kewenangan lokal berskala Desa didanai oleh APBDesa. Penyelenggaraan

\footnotetext{
36 Purwadarminta. Op.Cit. hlm. 74.

37 Pasal 1 ayat (7) Undang-Undang Nomor 6 Tahun 2014 Tentang Desa.
} 
kewenangan lokal berskala Desa selain didanai oleh APBDesa, juga dapat didanai oleh APBN dan APBD. Penyelenggaran kewenangan desa yang ditugaskan oleh Pemerintah didanai APBN yang dialokasikan pada bagiananggaran kementrian/lembaga dan disalurkan melalui satuan kerja perangkat daerah kabupaten/kota. Penyelenggaran kewenangan desa yang ditugaskan oleh Pemerintah Daerah didanai oleh APBD.

Materi muatan yang secara khusus disebut di dalam Undang-Undang No. 6 Tahun 2014 untuk ditetapkan dengan peraturan desa adalah pembentukan dusun atau dengan sebutan lain, susunan organisasi dan tata kerja pemerintah desa, Rencana Pembangunan Jangka Menengah Desa, Pengelolaan Keuangan Desa, Pembentukan Badan Usaha Milik Desa, dan Pembentukan Lembaga Kemasyarakatan. Menurut Pasal 69 ayat 3 UU No. 6 Tahun 2014, Peraturan Desa ditetapkan oleh Kepala Desa setelah dibahas dan disepakati bersama Badan Permusyawaratan Desa merupakan kerangka hukum dan kebijakan dalam penyelenggaran Pemerintahan Desa dan Pembangunan Desa. Penetapan Peraturan Desa merupakan penjabaran atas berbagai kewenangan yang dimiliki Desa mengacu pada ketentuan peraturan perundang-undangan yang lebih tinggi. Lebih lanjut Pasal 1 ayat 13 Permendagri No. 111 Tahun 2014 Tentang Pedoman Teknis Peraturan di Desa, peraturan Desa sebagai produk hukum tidak boleh bertentangan dengan peraturan yang lebih tinggi dan tidak boleh merugikan kepentingan umum, yaitu: terganggunya kerukunan antar warga masyarakat, terganggunya akses terhadap pelayanan publik, terganggunya ketentraman dan ketertiban umum, terganggunya kegiatan ekonomi untuk meningkatkan kesejahteraan masyarakat dan/atau diskriminasi terhadap suku, agama dan kepercayaan, ras, antar golongan, dan gender. ${ }^{38}$

Berdasarkan ketentuan Pasal 5 Permendagri No. 111 Tahun 2014 tentang Pedmoan Teknis Peraturan Desa, mekanisme pembentukan Peraturan Desa terdiri dari beberapa tahapan sebagai berikut:

1) Perencanaan; tahapan ini berupa penyusunan rancangan Peraturan Desa ditetapkan oleh Kepala Desa dan BPD dalam rencana kerja Pemerintah Desa. Lembaga kemasyarakatan, lembaga adat dan lembaga desa lainnya di desa dapat memberikan masukan kepada Pemerintah Desa dan atau BPD untuk rencana penyusunan rancangan Peraturan Desa;

2) Penyusunan; dimana tahapan ini Penyusunan rancangan Peraturan Desa dapat diprakarsai oleh Kepala Desa atau BPD. Penyusunan rancanagan Peraturan Desa yang diprakarsai oleh Pemerintah Desa wajib dikonsultasikan kepada masyrakat desa terutama kepada masyrakat atau kelompok masyarakat yang terkait langsung dengan substansi materi pengaturan. Selain itu, rancangan peraturan desa juga dapat Desa.

${ }^{38}$ Pasal 1 ayat 13 Permendagri No. 111 Tahun 2014 Tentang Pedoman Teknis Peraturan di 
dikonsultasikan kepada camat untuk mendapatkan masukan yang nantinya akan digunakan Pemerintah Desa untuk tindaklanjut proses penyusunan rancangan Peraturan Desa. Rancangan Peraturan Desa yang telah dikonsultasikan kepada masyarakat disampaikan Kepala Desa kepada BPD untuk dibahas dan disepakati bersama Rancangan Peraturan Desa yang disusun dan diusulkan oleh BPD kecuali untuk rancangan Peraturan Desa tentang pembangunan jangka menengah Desa, rancangan Peraturan Desa tentang rencana kerja Pemerintah Desa, rancangan Peraturan Desa tentang APB Desa dan rancangan Peraturan Desa tentang laporan pertanggung jawaban realisasi pelaksanaan APB Desa. Rancangan Peraturan Desa dapat diusulkan oleh anggota BPD kepada pimpinan BPD untuk ditetapkan sebagai rencangan Peraturan Desa usulan BPD;

3) Pembahasan; Dalam tahapan ini, BPD mengundang Kepala Desa untuk membahas dan menyepakati rancangan peraturan Desa. Dalam hal terdapat rancangan Peraturan Desa prakarsa Pemerintah Desa dan usulan BPD mengenai hal yang sama untuk dibahas dalam waktu pembahasan yang sama, maka didahulukan rancangan Peraturan Desa usulan BPD sedangkan Rancangan Peraturan Desa usulan Kepala Desa digunakan sebagai bahan untuk dipersandingkan. Rancangan Peraturan Desa yang belum dibahas dapat ditarik kembali oleh pengusul. Rancangan Peraturan Desa yang telah dibahas tidak dapat ditarik kembali kecuali atas kesepakatan bersama antara Pemerintah Desa dan BPD;

4) Penetapan; Rancangan peraturan Desa yang telah disepakati bersama disampaikan oleh pimpinan Badan Permusyawaratan Desa kepada kepala Desa untuk ditetapkan menjadi peraturan Desa paling lambat 7 (tujuh) Hari terhitung sejak tanggal kesepakatan. Rancangan peraturan Desa tersebut wajib ditetapkan oleh kepala Desa dengan membubuhkan tanda tangan paling lambat 15 (lima belas) Hari terhitung sejak diterimanya rancangan peraturan Desa dari pimpinan Badan Permusyawaratan Desa.

5) Pengundangan; Dalam tahap ini, Rancangan Peraturan Desa yang telah dibubuhi tanda tangan, disampaikan kepada Sekretaris Desa untuk diundangkan. Dalam hal Kepala Desa tidak menandatangani Rancangan Peraturan Desa tersebut, Rancangan Peraturan Desa tersebut wajib diundangkan dalam Lembaran Desa dan sah menjadi Peraturan Desa. Dalam tahapan setelahnya yaitu pengundangan, Sekretaris Desa mengundangkan peraturan desa dalam lembaran desa. Peraturan Desa dinyatakan mulai berlaku dan mempunyai kekuatan hukum yang mengikat sejak diundangkan;

6) Penyebarluasan. Tahapan yang terakhir adalah tahap Penyebarluasan. Penyebarluasan dilakukan oleh Pemerintah Desa dan BPD sejak penetapan rencana penyusunan rancangan Peraturan Desa, penyusunan Rancangan 
Peratuan Desa, pembahasan Rancangan Peraturan Desa, hingga Pengundangan Peraturan Desa. Penyebarluasan dilakukan untuk memberikan informasi dan/atau memperoleh masukan masyarakat dan para pemangku kepentingan ${ }^{39}$.

\section{E. Sinergitas Pemerintahan Desa Dalam Pembentukan Peraturan Desa}

Bentuk hubungan antara Badan Permusyawaratan Desa (BPD) dengan Pemerintahan Desa dapat disebut bersifat kemitraan, dimana hubungan kemitraan disini adalah Badan Permusyawaratan Desa (BPD) memiliki kedudukan yang sejajar dengan Pemerintah Desa namun tidak dapat mengendalikan organ-organ dari Pemerintah Desa. Sedangkan menurut ketentuan peraturan perundangundangan Pemerintah Desa sendiri dalam setiap pengambilan kebijakan yang menyangkut masyarakat desa harus berkonsultasi dengan Badan Permusyawaratan Desa (BPD).

Berdasarkan ketentuan Undang-Undang Nomor 6 Tahun 2014 Tentang Desa dikatakan bahwa kewenangan Badan Permusyawaratan Desa (BPD) juga meliputi kewenangan untuk membatalkan Peraturan Desa apabila peraturan tersebut tidak mencerminkan keadilan bagi masyarakat. Dalam hal ini juga Badan Permusyawaratan Desa (BPD) melaksanakan fungsinya untuk mengawasi kinerja dari Pemerintah Desa agar sesuai dengan peraturan yang berlaku. Apabila Pemerintah Desa melakukan peyimpangan maka Badan Permusyawaratan Desa (BPD) sebagai mitra berhak memberikan peringatan. Hubungan kemitraan antara Kepala Desa dengan Badan Permusyawaratan Desa (BPD) bertumpu pada kepercayaan, kerjasama dan saling menghargai. Dalam hubungan ini baik Pemerintah Desa maupun Badan Permusyawaratan Desa (BPD) saling bekerja sama, saling menghargai dan saling menghargai. Setiap pengambilan kebijakan Pemerintah Desa wajib berkonsultasi dengan Badan Permusyawaratan Desa (BPD). Ini berlaku juga dalam pembuatan Anggaran Pendapatan dan Belanja Desa (APBDesa) dan Peraturan Desa dengan kata lain hubungan kerja antara Pemerintah Desa dengan BPD dan lembaga Kemasyarakatan lainnya bersifat kemitraan, konsultatif dan koordinatif.

Kedudukan Kepala Desa dan Badan Permusyawaratan Desa (BPD) dapat dikatakan sebagai mitra kerja dalam proses pembentukan peraturan Desa, karena antara Badan Permusyawaratan Desa (BPD) bersama Kepala Desa akan menetapkan Peraturan Desa. Selain itu juga, Kepala Desa memimpin penyelenggaraan Pemerintahan Desa, Badan Permusyawaratan Desa (BPD) secarainstitusional mewakili masyarakat desa bertindak sebagai pengawas terhadap penyelenggaraan Pemerintahan Desa. Di sisi lain adanya fungsi Desa.

${ }^{39}$ Pasal 1 ayat 13 Permendagri No. 111 Tahun 2014 Tentang Pedoman Teknis Peraturan di 
Badan Permusyawaratan Desa (BPD) untuk menampung dan menyalurkan aspirasi masyarakat desa. Kepala Desa dan BPD harus memiliki pemahaman dan pemikiran yang sejalan dalam melaksanakan Pemerintahan Desa agar dapat terlaksana Pemerintahan Desa yang sesuai dengan harapan dan tuntutan masyarakat. Mengenai kemampuan melaksanakan tugas dan fungsi dapat dikatakan sebagai pelengkap dalam harmonisasi atau disharmonisasi hubungan kerja. Hubungan kerja dalam mekanisme kemitraan mengenai penetapan Peraturan Desa, pada kelaziman umum tedapat kondisi penyusunan rencana perundang-undangan dapat dilakukan oleh salah satu pihak, namun yang prinsip-prinsip rancangan peraturan perundang-undangan wajib mendapat persetujuan dari pihak lain sebagai mitra yang dtentukan. Hal yang sama berlaku dalam mekanisme peyusunan dan pengesahan Rancangan Peraturan Desa. Rancangan Peraturan Desa dapat dibuat oleh Kepala Desa atau Badan Permusyawaratan Desa (BPD) dan mendapat pengesahan dan persetujuan dari keduanya.

Pertanggungjawaban Kepala Desa secara normatif, tertuang dalam Pasal 27 Undang-Undang Nomor 6 Tahun 2014 Tentang Desa yakni Kepala Desa wajib menyampaikan laporan penyelenggaraan Pemerintahan Desa setiap akhir tahun anggaran kepada Bupati/Walikota, menyampaikan laporan penyelenggaraan Pemerintahan Desa pada akhir masa jabatan kepada Bupati/Walikota, memberikan laporan keterangan penyelenggaraan pemerintahan secara tertulis kepada Badan Permusyawaratan Desa setiap akhir tahun anggaran, dan memberikan dan/atau menyebarkan informasi penyelenggaraan pemerintahan secara tertulis kepada masyarakat desa setiap akhir tahun anggaran. ${ }^{40}$

Pertanggungjawaban Kepala Desa adalah hal pokok terutama dalam membangun 'trust' dan peningkatan pemberdayaan. Semenjak adanya otoritas formal ditingkat desa dalam bentuk institusi Pemerintahan Desa, Kepala Desa selalu lahir sebagai hasil pemilihan langsung oleh penduduk desa. Oleh karena itu wajar apabila Kepala Desa melaporkan kinerja yang telah dicapainya kepada penduduk yang memilihnya. Sebagai pemimpin yang terpilih, tampilan Kepala Desa adalah sosok yang terbuka apalagi dalam lingkungan masyarakat gemeinschaft, rasa tanggung jawab merupakan hal yang dijunjung tinggi, pemimpinlah yang pertama-tama harus bertanggungjawab terhadap kelompok yang dipimpinnya.

Kepala Desa pada dasarnya bertanggungjawab kepada rakyat yang prosedur pertanggung jawabannya disampaikan kepada Bupati/ Walikota melalui Camat. Sedangkan kepada Badan Permusyawaratan Desa, Kepala Desa wajib memberikan keterangan laporan pertanggungjawaban secara tertulis, dan kepada rakyat Kepala Desa menyampaikan informasi pokok-pokok

40 Pasal 27 Undang-Undang Nomor 6 Tahun 2014 Tentang Desa. 
pertanggung jawabannya lewat acara-acara yang dilakukan baik oleh Kepala Desa maupun oleh masyarakat desa. Pertanggungjawaban Pemerintah Desa dalam hal ini Kepala Desa mengalami perubahan yang mendasar. Sebelum lahirnya Undang-Undang Nomor 6 Tahun 2014 tentang Desa, Kepala Desa bertangungjawab kepada rakyat atau masyarakat melalui Badan Permusyawaratan Desa (BPD) sedangkan berdasarkan Undang-Undang Nomor 6 Tahun 2014 tentang Desa, pertanggungjawaban Kepala Desa disampaikan kepada Bupati melalui Camat, sedangkan ke Badan Permusyawaratan Desa (BPD) hanya sebatas memberikan keterangan dan/atau laporan atas pelaksanaan tugas Pemerintahan Desa. Hal ini berarti posisi Badan Permusyawaratan Desa dikurangi dan tidak sekuat dulu.

Dalam praktiknya sering terjadi hubungan yang tidak harmonis antara Kepala Desa dengn Badan Permusyawaratan Desa (BPD) hal ini terlihat dalam proses penyusunan dan penetapan Anggaran Pendapatan Belanja Desa(APBDes), pelaksanaan Peraturan Desa, pelaksanaan pembangunan Desa dan pelaksanaan pertanggungjawaban Kepala Desa. Hubungan kerja antara Kepala Desa dan Badan Permusyawaratan Desa (BPD) dalam proses tersebut, menunjukkan adanya ketergantungan yang begitu besar dari Kepala Desa atas kebijakan penyaluran anggaran APBDes. Sehingga sering kali kondisi demikian menimbulkan ketidakharmonisan antara Kepala Desa dengan Badan Permusyawaratan Desa (BPD).

Hubungan kerja antara Kepala Desa dan Badan Permusyawaratan Desa (BPD) dalam melaksanakan Pemerintahan Desa yang demokratis harus sejalan dan kompak karena demi untuk mewujudkan kesejahteraan masyarakat desa. Dalam mencapai pemerintahan yang demokratis antara Kepala Desa dan Badan Permusyawaratan Desa serta kelembagaan desa lainnya pola hubungannya harus seimbang dan berjalan professional sesuai dengan kedudukan, tugas dan fungsinya masing-masing serta dilakukan dengan iktikad baik. Kepala Desa dan Badan Permusyawaratan Desa harus tetap duduk bersama melakukan konsutasi dan koordinasi dan saling bekerja sama dengan cara mengadakan rapat atau musyawarah dalam hal penyelenggaraan Pemerintahan Desa, pelaksanaan pembangunan desa, pembinaan kemasyarakatan Desa dan Pemberdayaan masyarakat desa. Perwujudan demokrasi di desa dalam bentuk model pengambilan keputusan dengan menggunakan musyawarah untuk mencapai mufakat dalam berbagai permasalahan yang dihadapi.

Musyawarah Desa merupakan forum tertinggi dalam mengambil keputusan atas masalah-masalah strategis desa. Dalam penyelenggaraan Pemerintahan Desa partisipasi masyarakat dalam kegiatan pembangunan sangat diharapkan. Kepala Desa dalam melaksanakan tugas pembangunan dan penyelenggaraan pelayanan kepada masyarakat harus memperhatikan saran 
dan serta masukan yang berasal dari Badan Permusyawaran Desa (BPD) atau masyarakat desa. Untuk membangun pemerintahan yang demokratis antara Kepala Desa dan Badan Permusywaratan Desa, harus bersinergi dengan baik, mempunyai pikiran yang sejalan.

Hubungan kerja antara Kepala Desa dan BPD dalam bentuk kemitraan, konsultasi dan koordinasi ini harus jelas diatur dalam Peraturan Desa agar dapat dipahami dan dijalankan oleh kedua belah pihak, supaya tidak terjadi salah kaprah dalam pelaksanaan tugas dan fungsi masing-masing, disamping itu juga untuk dapat meminimalisir konflik yang terjadi antara Kepala Desa dengan Badan Permusyawaratan Desa. Kemitraan, konsultasi dan koordinasi diperlukan dalam penyelenggaraan Pemerintahan dalam bidang pemerintahan, bidang pembangunan maupun dalam rangka memberikan pelayanan kepada masyarakat, semua penyelenggara Pemerintahan Desa, Kepala Desa, Sekretariat Desa dan aparatur desa lainnya, bersama Badan Permusyawaratan Desa harus benar-benar memahami kapasitas yang menjadi kewenangan maupun tugasnya masing-masing sehingga dalam melaksanakan pelayanan dan penyelenggaraan Pemerintahan Desa dapat berjalan dan bersinergi dengan baik untuk mewujudkan Pemerintahan Desa yang profesional, aspiratif, partisifatif dan akuntabel.

Pola kemitraan hubungan kerja antara Kepala Desa dan BPD dalam hal pembutan Rancangan Peraturan Desa, bahwa sebuah Rancangan Peraturan Desa baik yang berasal dari Kepala Desa maupun yang diusulkan oleh Badan Permusyawaratan Desa harus dibahas secara bersama, kemudian ditetapkan oleh Kepala Desa atas persetujuan bersama dengan Badan Permusyawaratan Desa untuk menjadi Peraturan Desa. Namun sebelum mendapat pengesahan bersama terlebih dahulu dimintakan persetujuan dari masyarakat desa lewat musyawarah Desa yang khusus diadakan untuk membicarakan hal ini masyarakat dapat diajukan melalui Kepala Dusun atau Anggota BPD, jika aspirasi disampaikan melalui Kepala Dusun, maka akan disampaikan ke Kepala Desa kemudian disampaikan kepada BPD untuk dibahas dan diputuskan bersama untuk dilaksanakan, selanjutnya jika aspirasi tersebut disampaikan lewat anggota Rancangan Badan Permusyawaratan Desa (BPD), diteruskan kepada Ketua BPD kemudian dirapatkan dalam Musyawarah BPD hasil musyawarah tersebut selanjutnya disampaikan kepada Kepala Desa untuk ditindaklanjuti.

Selain itu dalam pembuatan Anggaran Pendapatan dan Belanja Desa (APBDes) harus dibahas bersama oleh Badan Permusyawaratan Desa (BPD) dan Pemerintah Desa. Hal itu juga berlaku dalam pembuatan Peraturan Desa dan pengambilan kebijakan. Karena Badan Permusyawaratan Desa (BPD) dalam hal ini sebagai mitra dari Pemerintah Desa maka Badan Permusyawaratan Desa (BPD) berkewajiban memperingatkan Pemerintah Desa apabila dalam penyelenggaraan 
Pemerintahan Desa, Pemerintah Desa melakukan penyimpangan. Sebagai mitra Badan Permusyawaratan Desa (BPD) juga melakukan fungsi pengawasan terhadapa jalannya Peraturan Desa. Apabila Peraturan Desa tersebut tidak mampu mewujudkan keadilan dan/atau meresahkan masyarakat, maka Badan Permusyawaratan Desa (BPD) dapat mengajukan pembatalan Peraturan Desa kepada Pemerintah Daerah Kabupaten untuk dilakukan evaluasi terhadap Peraturan Desa tersebut.

\section{PENUTUP}

\section{A. Kesimpulan}

Berdasarkan uraian di atas, maka dapat diambil kesimpulan bahwa sinergitas antara Kepala Desa dan Badan Permusyawatan Desa (BPD) dalam Proses Pembentukan Peraturan Desa diwujudkan dalam bentuk kemitraan, dimana kedudukan antara Badan Permusyawaratan Desa (BPD) dan Pemerintah Desa sejajar kewenangan yang dimiliki dalam pembentukan berbeda baik mulai dari tahapan perencanaan, penyusunan, pembahasan, penetapan dan pengundangan serta penyebarluasan Peraturan Desa. Selain itu juga Badan Permusyawaratan Desa (BPD) berwenang juga memiliki fungsi pengawasan terhadap pelaksanaan Peraturan Desa oleh Kepala Desa. Adapun bila Peraturan Desa tersebut tidak dapat dijalankan dengan baik serta tidak mampu mewiudkan keadilan bagi masyarakat, maka Badan Permusyawaratan Desa (BPD) memiliki wewenang untuk membatalkan Peraturan Desa yang telah ditetapkan bersama dengan Kepala Desa maupun yang telah dilaksanakan oleh Kepala Desa dimana Badan Permusyawaratan Desa (BPD) dapat mengajukan pembatalan Peraturan Desa tersebut kepada Pemerintah Daerah Kabupaten melalui Camat untuk dilakukan evaluasi terhadap Peraturan Desa tersebut.

\section{B. Saran}

Melihat kewenangan Badan Permusyawaratan Desa (BPD) yang kurang optimal, hendaknya kewenangan dari Badan Permusyawaratan Desa (BPD) tersebut diperluas. Selain itu hendaknya dibuat Peraturan Daerah yang mengatur tentang fungsi kemitraan antara Badan Permusyawaratan Desa (BPD) dengan Pemerintah Desa dapat berjalan dengan baik. Selain itu juga, perlu lebih ditingkatkan lagi kerjasama dan koordinasi antara Pemerintah Desa dengan Badan Permusyawaratan Desa (BPD) dengan peningkatan kesadaran mengenai hak dan kewajiban masing-masing pihak agar tidak terjadi saling melampaui wewenang dan tanggung jawab. 


\section{DAFTAR PUSTAKA}

\section{A. Buku-buku}

Agus Dwiyanto, dkk. 2003. Reformasi Tata Pemerintahan dan Otoromi Daerah. Pusat Studi Kependudukan dan Kebijakan Universitas Gadjah Mada, Yogyakarta.

Amrah Muslimin. 2006. Aspek-aspek Hukum Otonomi Daerah. Alumni, Bandung.

Ateng Syafrudin dan Suprin Na'a. 2010. Republik Desa, Pergulatan Hukum Tradisional dan Hukum Modern dalam Desain Otonomi Desa. Alumni ,Bandung.

Bagir Manan. 2005. Menyongsong Fajar Otonomi Daerah. Pusat Studi Hukum Fakultas Hukum Universitas Islam Indonesia.

F. Magnis Suseno. 2006. Etika Politik, Prinsip - Prinsip Moral Dasar Kenegaraan Modern. Gramedia, Jakarta.

Fadjar, A. Mukthie. 2005. Tipe Negara Hukum. Cet. Kedua. Bayumedia Publishing, Malang.

H.Mc.Coubrey and N.D.White. 2003. Text Book On Jurisprudensi. Blakstone Press Limited, London.

Indra Ismawan. 2002. Raniau-Ranlau Otonomi Daerah. Pondok Edukasi, Solo.

Ismulyadi dkk. 2000. Otonomi Daerah, Demokrasi dan Cipil Society. Media Grafika Cetakan 1, Jakarta.

Joeniarto. 2006. Negara Hukum. Yayasan Badan Penerbit Gadjah Mada, Yogyakarta.

K. C. Wheare. 2010. Modern Constitution. Oxford University Press, New York.

Lawrence M Friedman.2011. Sistem Hukum Perspektif Ilmu Sosial. Nusa Media Bandung.

Muchsan. 2012. Pengantar Hukum Administrasi Negara. Liberty, Yogyakarta.

Ni'matul Huda. 2015. Hukum Pemerintahan Desa. Setara Press, Malang.

Siswanto Sunarno. 2006. Hukum Pemerintahan Daerah di Indonesia. Sinar Grafika, Jakarta. 
Sutoro Eko. 2005. Masa Lalu, MasaKini dan Masa Depan Otonomi Desa, dalam Soetandyo Wignosubroto dkk (Tim Penulis). 2005. Pasang surut Otonomi Daerah, Sketsa Perjalanan 100 Tahun. Institute for Local Development dan Yayasan Tifa, Jakarta.

\section{B. Peraturan Perundang-Undangan Lainnya}

Undang-Undang Dasar Negara Republik Indonesia Tahun 1945.

Undang-Undang Nomor 6 Tahun 2014 Tentang Desa

Peraturan Pemerintah Nomor 47 Tahun 2015 tentang Perubahan Atas Peraturan Pemerintah Nomor 43 Tahun 2014 tentang Peraturan Pelaksanaan UndangUndang Nomor 6 Tahun 2014 tentang Desa.

Permendagri No. 111 Tahun 2014 Tentang Pedoman Teknis Peraturan di Desa.

\section{Sumber Lainnya}

Attamimi, A. Hamid S. 2010. Peranan Keputusan Presiden Republik Indonesia Dalam Penyelenggaraan Pemerintahan Negara, Suatu Studi Analisa Mengenai Keputusan Presiden Yang Berfungsi Pengaturan Dalam Kurun Waktu Pelita IPelita IV. Disertasi Universitas Indonesia, Jakarta.

Purwadarminta. 2008. Kamus Besar Bahasa Indonesia. Balai Pustaka, Jakarta. 


\section{PEDOMAN PENULISAN \\ JURNAL PRANATA HUKUM}

1. Naskah bersifat orisinil, baik berupa hasil riset atau tinjauan atas suatu permasalahan hukum yang berkembang di masyarakat (artikel lepas), dimungkinkan juga tulisan lain yang dipandang memberikan kontribusi bagi pengembangan ilmu hukum.

2. Penulisan terdiri atas beberapa bab penulisan hasil penelitian terdiri dari $3 \mathrm{BAB}$, yaitu ;

BAB I. PENDAHULUAN (Latar Belakang dan Rumusan Masalah) BAB II. PEMBAHASAN (Kerangka Teori dan Analisis), dan BAB III. PENUTUP (Kesimpulan dan Saran).

3. Tulisan menggunakan bahasa indonesia maupun bahasa inggris yang memenuhi kaidah bahasa yang baik dan benar,tulisan menggunakan bahasa indonesia disertai abstrak dalam bahasa inggris (200 kata) dan Kata kunci, ketentuan ini berlaku sebaliknya.

4. Setiap kutipan harus menyebutkan sumbernya dengan format footnote. Sumber kutipan harus memuat nama pengarang, tahun penerbitan, judul buku, nama penerbit, kota penerbit, dan halaman. Contoh : Bagir Manan. 1994. Hubungan Antara Pemerintah Pusat dan Daerah Menurut UUD 1945. Pustaka Sinar Harapan. Jakarta. 1994, hlm. 19. Untuk artikel dari internet dengan susunan: nama penulis, judul tulisan digaris bawah, alamat website, waktu download/unduh.

5. Naskah harus disertai dengan daftar pustaka atau referensi ,terutama yang digunakan sebagai bahan acuan langsung. Daftar pustaka dan referensi bersifat alfabetis dengan format; nama pengarang, judul buku, nama penerbit, kota terbit, dan tahun penerbitan. Contoh: Bagir Manan. 1994. Hubungan Antara Pemerintah Pusat dan Daerah Menurut UUD 1945. Pustaka Sinar Harapan. Jakarta.

6. Panjang tulisan antara 15-25 halaman, font cambria dengan 1,15 spasi. Dalam hal hal tertentu berlaku pengecualian panjang tulisan.

7. Naskah disertai nama lengkap penulis, alamat e-mail dan lembaga tempat berafiliasi saat ini, dan hal lain yang dianggap penting. 
Jurnal PRANATA HUKUM dimaksudkan sebagai media komunikasi, edukasi, dan informasi ilmiah bidang ilmu hukum khususnya, dan ilmu sosial pada umumnya. Sajian dan kemasan diupayakan komunikatif melalui bahasa ilmiah.

Redaksi mengundang semua elemen masyarakat baik civitas akademika, praktisi, lembaga masyarakat, maupun perorangan yang berminat terhadap bidang hukum untuk berpartisipasi mengembangkan gagasan, wawasan, dan pengetahuan melalui tulisan untuk dimuat dalam jurnal ini.

Melalui PRANATA HUKUM diharapkan terjadi proses pembangunan dan pengembangan bidang hukum sebagai bagian penting dari rangkaian panjang proses memajukan masyarakat bangsa.
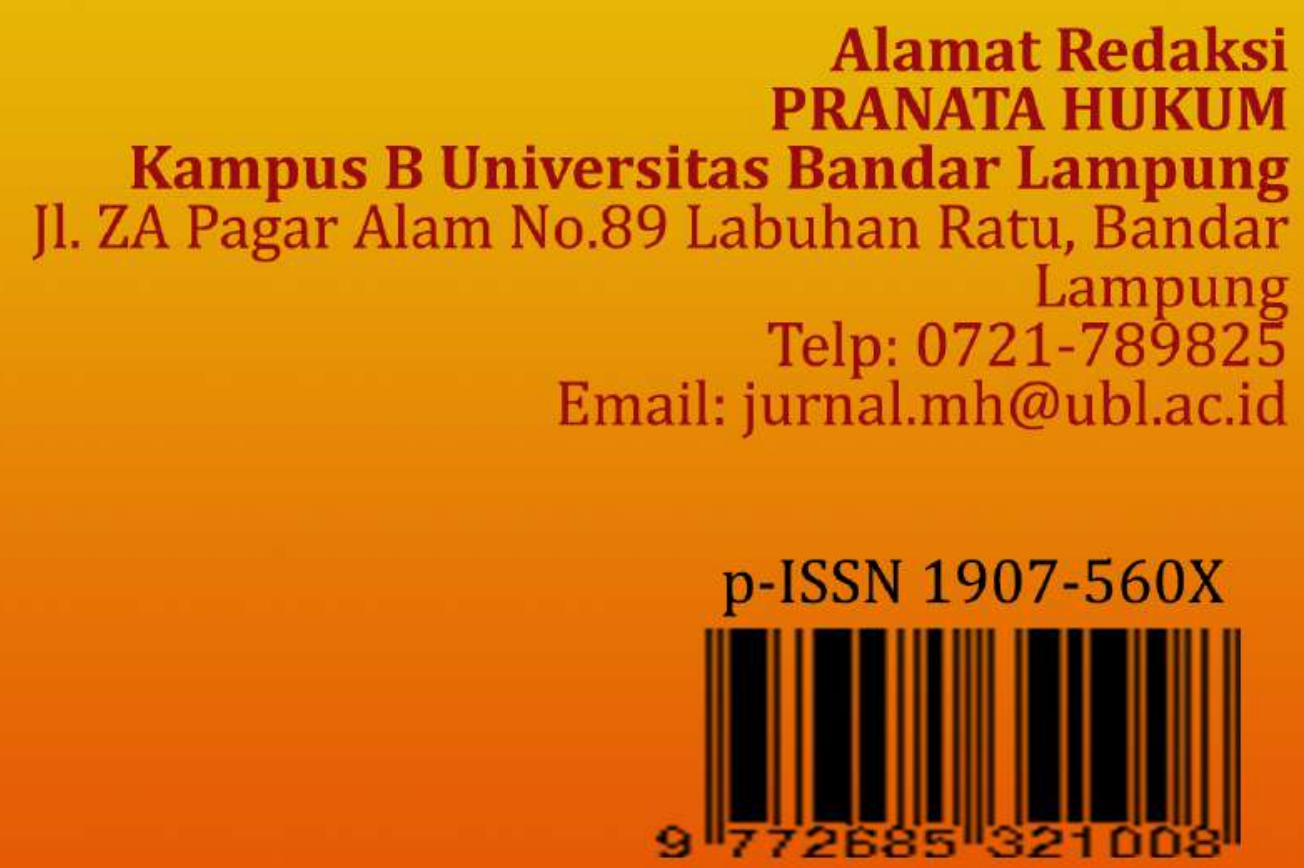